ISSN 1978-2071 (Print); ISSN 2580-5967 (Online)

Jurnal IImiah Kedokteran Wijaya Kusuma 8(2) : 108-117, September 2019

\title{
Analisis Ekspresi Protein TLR-9, CD90 dan VEGF pada Mesenchymal Stem Cell di Jaringan Tumor Osteosarkoma
}

\author{
Pratika Yuhyi Hernanda \\ Laboratorium Genetika Medik, Bagian Biomedik, Fakultas Kedokteran, \\ Universitas Wijaya Kusuma Surabaya \\ e-mail: yuhyi_h@yahoo.com
}

\begin{abstract}
Abstrak
Untuk penelitian lebih jauh terhadap efek Mesenchymal Stem Cell (MSC) pada pertumbuhan tumor/kanker, maka perlu diawali dengan analisa profil MSC dari jaringan tumor/kanker yang dalam penelitian ini diwakili oleh MSC dari jaringan osteosarkoma. Metode analisa profil MSC yang kami gunakan adalah fenotip MSC dari jaringan tumor osteosarkoma dibandingkan dengan jaringan adiposanormal serta karakteristik MSC dalam hal ini diwakili oleh ekspresi protein beberapa kandidat gen yaitu TLR-9, CD-90 dan VEGF. Dari hasil pewarnaan immunofluorescence yang dilakukan pada MSC adiposa dibandingkan dengan MSC osteosarkoma terlihat walaupun secara umum fenotip keduanya mirip, tidak terdapat perbedaan yang signifikan pada ekspresi CD-90 pada MSC osteosarkoma dan MSC adiposa. Ekspresi VEGF walaupun terlihat sedikit menonjol pada MSC osteosarkoma namun perbedaan antara keduanya juga tidak signifikan. Sedangkan ekspresi TLR9 sangat menonjol pada MSC osteosarkoma dan terdapat perbedaan yang signifikan dengan MSC adiposa. Dengan demikian TLR9 dapat menjadi perhatian pada penelitian selanjutnya untuk menelaah mekanisme MSC yang memicu pertumbuhan tumor.
\end{abstract}

Kata Kunci: TLR-9, CD90, VEGF, mesenchymal stem cell

\section{Analysis of TLR-9, CD90 and VEGF Expressions in the tumor - Osteosarcoma Mesenchymal Stem Cell}

\begin{abstract}
For further investigation on the effect of Mesenchymal Stem Cell (MSC) on tumor / cancer growth, it is necessary to start with tumor MSC profile from tumor / cancer tissue. In this study, we use MSC from osteosarcoma tissue as a representative. The MSC profile analysis method used were the comparing the phenotype and characteristics of MSC fromosteosarcoma tissue with MSC from normal adiposa tissue. The characteristics of MSC were represented by protein expression of several candidate genes namely TLR-9, CD-90 and VEGF. From the results of immunofluorescence staining on adiposa MSC compared withosteosarcoma MSC, it has obviously seen that although the phenotypes were similar, there was no significant difference in CD-90 expression in osteosarcoma MSC and adiposa MSC. Although VEGF expression appears to be slightly prominent in osteosarcoma MSCs, the difference between the two was also not significant. Whereas TLR9 expression is very prominent in osteosarcoma MSC and significantly different from adiposa MSC. Thus TLR9 may be of concern in subsequent studies to investigate the mechanism of MSC triggers tumor growth.
\end{abstract}

Keyword: TLR-9, CD90, VEGF, mesenchymal stem cell 
Analisis Ekspresi Protein TLR-9, CD90 dan VEGF pada Mesenchymal Stem Cell di Jaringan...

Pratika Yuhyi Hernanda

\section{PENDAHULUAN}

Salah satu terapi untuk tumor atau kanker di Indonesia adalah terapi stem cell atau lebih lengkapnya Mesenchymal Stem Cell (MSC). Studi ilmiah mengenai MSC sebagai terapi penyakit sudah banyak dilakukan namun kontradiksi mengenai hasil dari penelitian itu tetap masih ada.Sebagai bagian dari lingkungan mikro (microenvironment) didalam jaringan tubuh manusia, utamanya pada jaringan tumor atau kanker, MSC memiliki karakteristik dapat berdiferensiasi secara multi-lineage menjadi bermacam-macam sel (Horwitz et al, 2005). Sel kanker sendiri dapat menyusup ke jaringan sekitar dan dapat membentuk anak sebar merupakan salah satu penyakit yang tidak menular di Indonesia yang diprediksi akan terus bertambah.

Mesenchymal stem cells (MSCs) adalah sel stroma multipotent yang dapat diidentifikasi secara invitro dan memiliki kemampuan untuk membentuk koloni serta dapat berdiferensiasi secara osteogenik, adipogenik dan chondrogenik. MSCs juga memproduksi faktor tropis dengan kemampuan sebagai immunomodulator, anti apoptosis dan pro angiogenesis yang dapat mempengaruhi perilaku sel sekitarnya (Sobacchi et al, 2017). Jika kita menilik pada ekologi kanker, maka kanker dapat disebabkan oleh beberapa hal di level lingkungan makro (macro-environment) dengan keterpaparan bahan-bahan karsinogenik (virus, rokok, aflatoksin, pollutan, agen biologis, dan lain-lain) serta lingkungan mikro (microenvironment) dengan mekanisme karsinogenesisnya di level individu. Lingkungan mikro termasuk didalamnya adalah reaksi-reaksi biokimia dan proses molekuler yang terjadi dalam tubuh manusia (Vineis et al, 2017). MSC merupakan bagian dari lingkungan mikro (micro-environment) dimana pengaruh MSCs pada tumor/kanker itu sendiri akan sangat bergantung pada konteks lingkungan mikro dimana ia berada. Oleh karena banyaknya faktor yang mempengaruhi pertumbuhan sel kanker, maka perilaku sel kanker serta respon terhadap terapi tentu juga akan sangat bervariatif, ditentukan oleh faktor-faktor tersebut diatas.

MSC bermigrasi ke jaringan tumor atau kanker pada proses inflamasi dimana terjadi reaksi-reaksi imunologi dan sel-sel inflamasi. Migrasi MSC ini melibatkan banyak faktor, diantaranya faktor intrinsik dan faktor ekstrinsik, yang membuat keberadaan MSC menjadi pertanda adanya sel kanker (Hernanda et al. 2013a). Namun peran MSC masih bersifat dualistik dimana beberapa studi melaporkan efek MSC dapat memicu pertumbuhan tumor dan 
ISSN 1978-2071 (Print); ISSN 2580-5967 (Online) Jurnal IImiah Kedokteran Wijaya Kusuma 8(2) : 108-117, September 2019

beberapa melaporkan MSC dapat menghambat pertumbuhan tumor (Hernanda et al, 2014). Selain faktor perbedaan jenis dan sumber MSC yang digunakan, faktor-faktor yang mempengaruhi efek akhir MSC akan sangat terkait dengan kondisi lingkungan mikro dimana MSC tersebut berada. Pada akhirnya, oleh karena keuntungan dan manfaat terapi infused MSC yang kurang jelas pada pasien kankerdan potensi untuk pertumbuhan tumor oleh MSC yang telah dibuktikan pada berbagai percobaan serta kemungkinan transformasi maligna MSCmaka disarankan agar pemakaian MSC pada kasus-kasus tumor atau kanker ditunda terlebih dahulu sampai bukti-bukti dapat menunjukkan keamanan MSC pada kasus kanker (Hernanda et al, 2014).

Untuk penelitian lebih jauh terhadap efek MSC pada pertumbuhan tumor/kanker, maka perlu diawali dengan analisa profil MSC dari berbagai jaringan tumor/kanker. Untuk itulah, maka penelitian ini dilakukan. Metode analisa profil MSC yang kami gunakan adalah fenotip MSC dari jaringan tumor dan jaringan adiposa serta karakteristik MSC dalam penelitian ini diwakili oleh ekspresi beberapa kandidat gen yaitu TLR-9, CD-90 dan VEGF dimana kandidat gen tersebut sangat berperan penting dalam pertumbuhan dan penyebaran sel-sel tumor/kanker (Huynh et al, 2016; Zhao and Peehl 2009; Martinez-Campos et al, 2017; Beckermann et al, 2008). CD-90 (Cluster of Differentiation 90) adalah protein pada permukaan sel yang dapat digunakan sebagai penanda pada berbagai stem cell (Ades et al, 1980). Adapun Vascular Endothelial Growth Factor (VEGF) adalah protein sinyal yang dihasilkan oleh sel yang menstimulasi pembentukan pembuluh darah yang terlibat dalam vasculogenesis dan angiogenesis (Senger et al, 1983). Sedangkan TLR9 adalah reseptor penting yang diekspresikan dalam sel-sel imun termasuk sel dendritik, makrofag, sel NK, dan sel-sel penyaji antigen lainnya dalam sel stroma lingkungan mikro (Du et al, 2000). Analisa profil MSC ini akan sangat berguna pada penelitian lebih lanjut untuk melihat pengaruh MSC pada perkembangan sel tumor/kanker.

\section{METODE}

\section{Kultur Sel}

Untuk mengkultur MSC, jaringan tumor/kanker akan dipotong menjadi beberapa bagian yang kecil seperti yang telah dijelaskan sebelumnya (Hernanda et al, 2013b) dan kemudian dicacah serta dicuci dengan phospat buffer saline (PBS) untuk kemudian di kultur dalam 12 well plate dengan pemberian medium DMEM (Lonza, Belgium) dan suplementasi 10\% 
Analisis Ekspresi Protein TLR-9, CD90 dan VEGF pada Mesenchymal Stem Cell di Jaringan... Pratika Yuhyi Hernanda

fetal bovine serum (FBS), $100 \mathrm{IU} / \mathrm{ml}$ penicillin, dan $100 \mathrm{lg} / \mathrm{ml}$ streptomycin. Kultur dilakukan didalam inkubator dengan suhu $37 \mathrm{C}$ dan tekanan $\mathrm{CO} 25 \%$. Kultur berlangsung selama 2-3 minggu sampai munculnya fibroblast like cell disekitar jaringan tumor yang ditanam. Setelah itu, jaringan dibuang dan MSC di kultur kembali dengan kondisi yang sama untuk nantinya dianalisa fenotip serta kemampuan proliferasi dan migrasi sel nya.

\section{Immunofluoresence}

Immunofluorescence dilakukan selain untuk memberi pewarnaan pada badan sel MSC sehingga pemantauan fenotip MSC dapat dilakukan dengan lebih jelas dibawah kamera juga dilakukan untuk melihat daya absorbansi marker-marker tertentu (VEGF, TLR dan CD90) untuk dibandingkan antara sel MSC normal dan MSC tumor. MSC yang dikultur dalam 2 well plate akan di kultur dengan meletakkan coverslip didalamnya. Setelah satu minggu kultur dan sel cukup banyak

\section{MSC Adiposa}

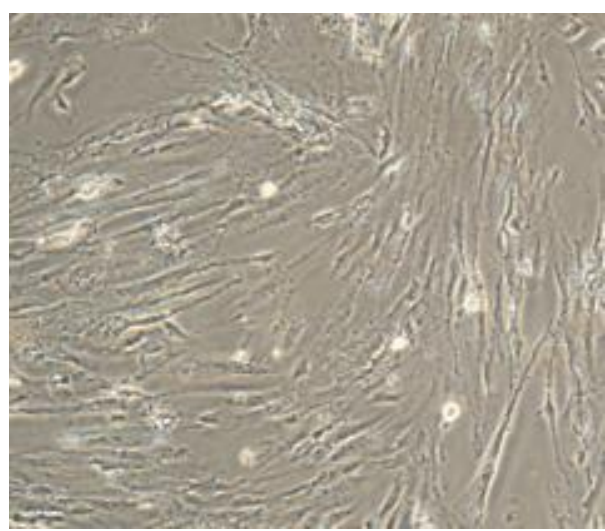

dalam coverslip maka dilakukan pemeriksaan ketiga marker tersebut diatas dengan diteteskan pada coverslip yang telah diletakkan terlebih dahulu pada obyek glass. Sebelum analisa, sel terlebih dahulu dicuci dengan PBS dan difiksasi dengan methanol $4 \%$ selama 5 menit. Objek glass siap untuk dianalisa di bawah mikroskop fluoresence.

\section{HASIL}

Secara umum, fenotip kedua sel MSC dari jaringan normal adiposa dan jaringan tumor osteosarkoma tidak jauh berbeda, yaitu berbentuk fibroblast like cell, pipih dan memanjang seperi halnya namanya, mesenchymal. Terlihat MSC dari jaringan osteosarkoma permukaannya lebih rata daripada MSC adiposa. Hal ini bisa dikarenakan oleh usia passage yang lebih lama untuk MSC adiposa daripada MSC osteosarkoma. Setelah itu, MSC dilakukan pewarnaan immunofluorescence CD-90, TLR-9 dan VEGF.

\section{MSC Osteosarkoma}

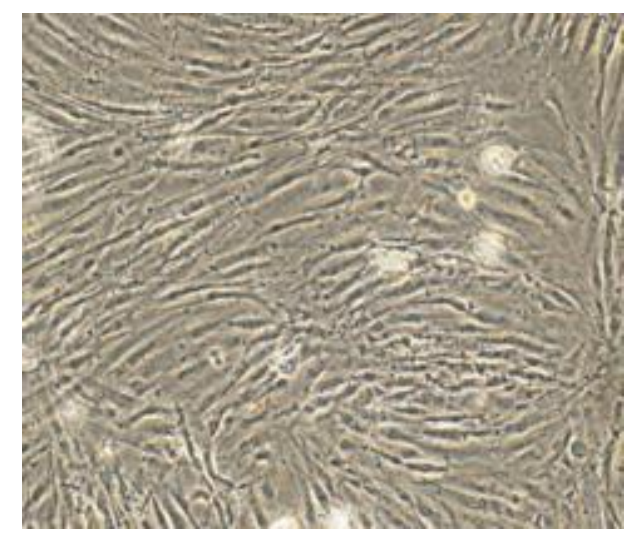

Gambar 1. MSC dari jaringan adiposa dan osteosarkoma 
ISSN 1978-2071 (Print); ISSN 2580-5967 (Online) Jurnal IImiah Kedokteran Wijaya Kusuma 8(2) : 108-117, September 2019

Immunofluorescence

Plain

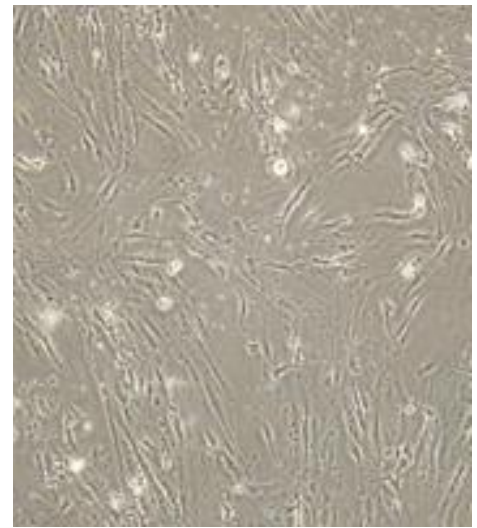

MSC Osteosarkoma

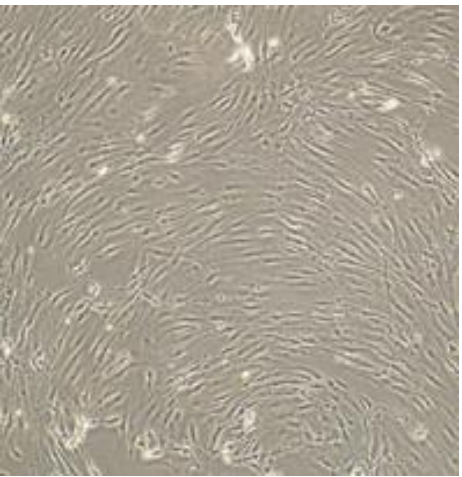

Gambar 2. Ekspresi CD-90 pada MSC

CD90

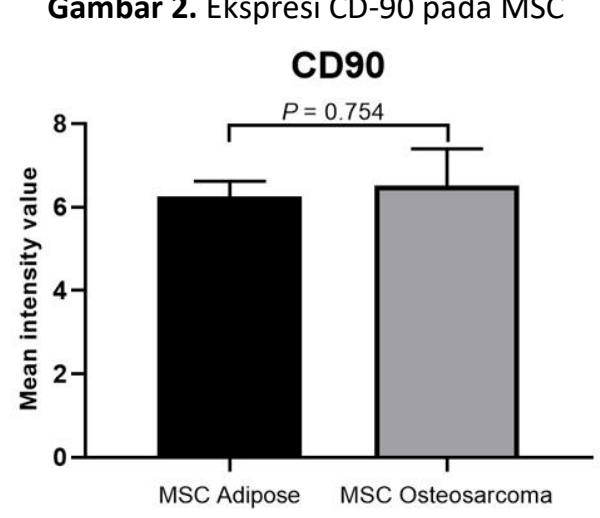

Fluorescence
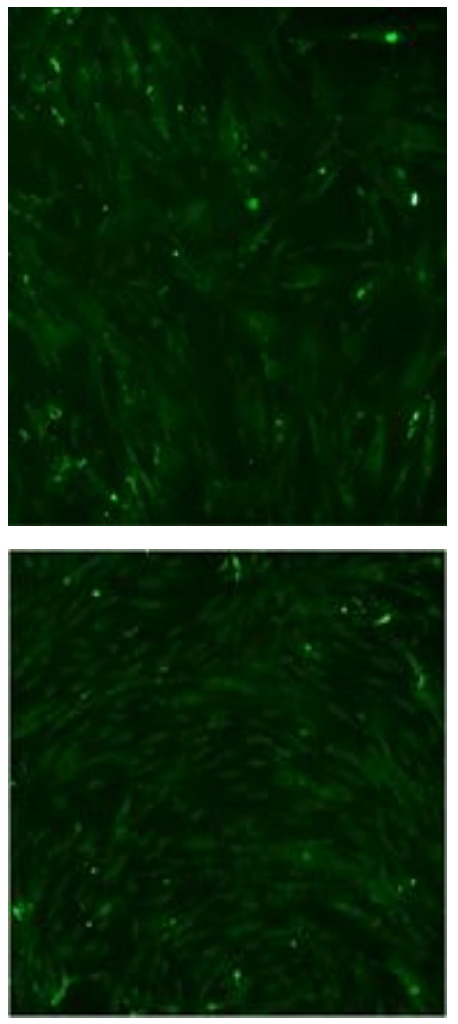

Gambar 3. Intensitas rata-rata pada immunostaining CD90 pada MSC adiposa dan MSC Osteosarkoma

Dari gambar 2 di atas, terlihat bahwa ekspresi CD-90 secara umum ada pada MSC. Ekspresi CD-90 pada MSC osteosarkoma terlihat lebih tinggi dibandingkan pada MSC adiposa namun tidak ada perbedaan yang signifikan antara keduanya dengan $P$ value $=0.754$ (Gambar 3). 
Analisis Ekspresi Protein TLR-9, CD90 dan VEGF pada Mesenchymal Stem Cell di Jaringan... Pratika Yuhyi Hernanda

Immunofluorescence

Plain

Adiposa

Osteosarkoma
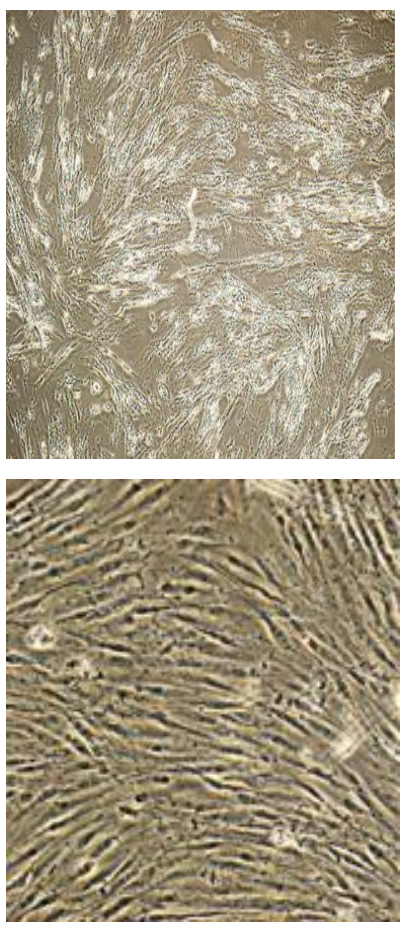

Gambar 4. Ekspresi TLR-9 pada MSC
TLR-9

Fluorescence
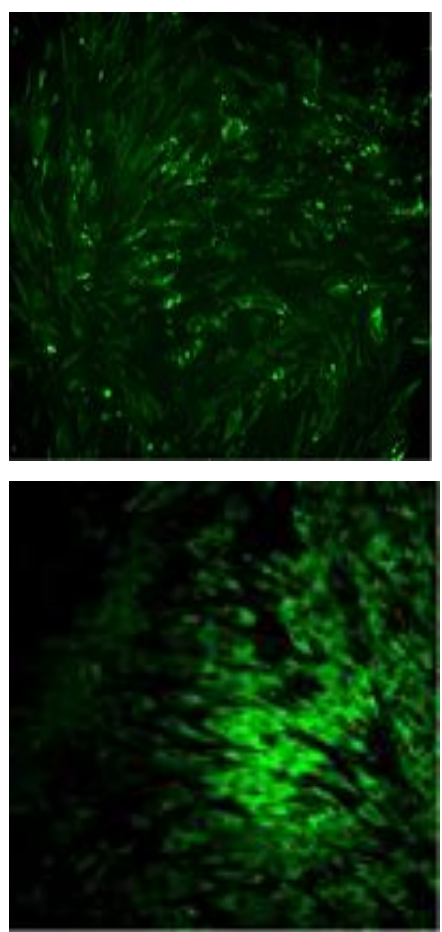

Gambar 5. Intensitas rata-rata pada immunostaining TLR9 pada MSC adiposadan MSC Osteosarkoma

Dari Gambar 4 di atas, terlihat bahwa ekspresi TLR9 sangat menonjol pada MSC osteosarkoma dan terdapat perbedaan yang signifikan dengan MSC adiposa dengan dengan $P$ value $=0.001$
(Gambar 5). Sedangkan ekspresi VEGF walaupun terlihat sedikit menonjol pada MSC osteosarkoma namun perbedaan antara keduanya tidak signifikan dengan $P$ value $=0.066$ (Gambar 6 dan 7).

\section{VEGF}

Plain

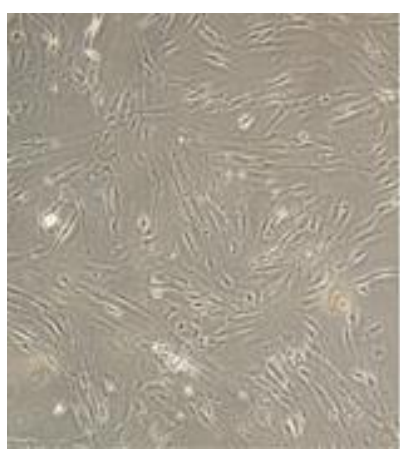

Fluorescent

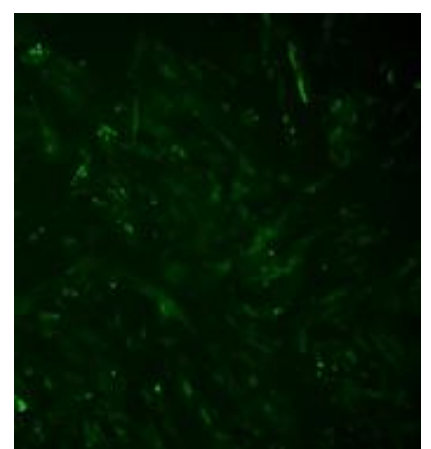



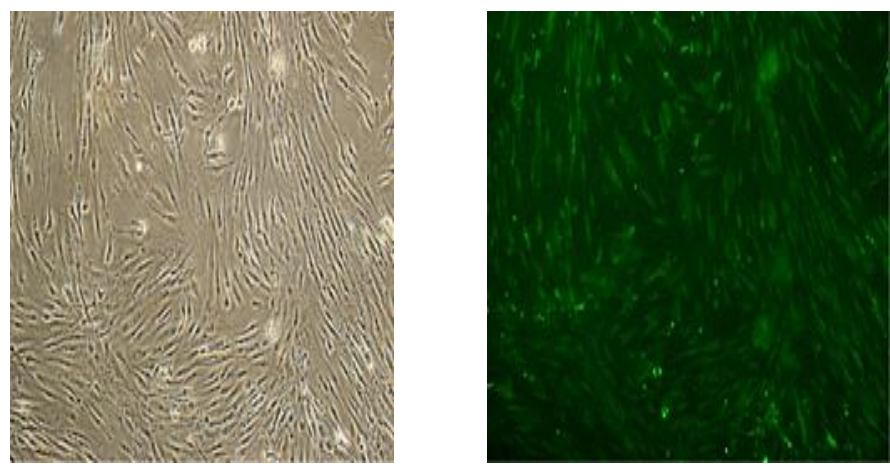

Gambar 6. Ekspresi VEGF pada MSC

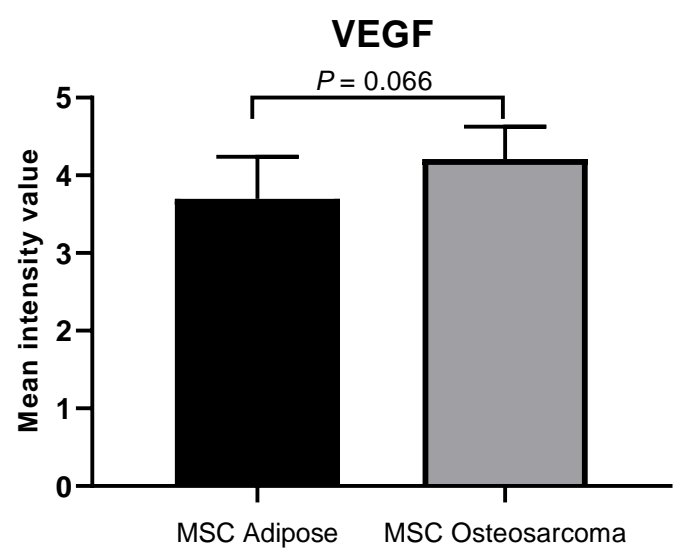

Gambar 7. Intensitas rata-rata VEGF pada MSC adiposa dan MSC osteosarkoma

\section{PEMBAHASAN}

Tumor padat dianggap sebagai "organ" yang terdiri dari sel kanker dan lingkungan mikro tumor. Lingkungan mikro tumor mencakup extracellular matrix (ECM), sel induk mesenchymal (MSC), sel endotel, sel imun, dan, lebih jauh lagi, jaringan sitokin dan faktor pertumbuhan. Mesenchymal stem cell di jaringan tumor juga membutuhkan lingkungan mikro khusus yang dikenal sebagai 'niche' untuk mengatur proliferasi dan menyelamatkan sel induk dari pengurangan (Xie and Li,
2007). Lingkungan mikro yang mengelilingi mesenchymal stem cell di jaringan tumormemainkan banyak peran termasuk sebagai jangkar mekanis untuk sel induk dan cross talk yang dimediasi oleh faktor kontak langsung dan/atau faktor ekstraselular tidak langsung.

Mesenchymal stem cell dari jaringan tumor memiliki interaksi kompleks dengan komponen lingkungan mikro tumor. Sitokin memainkan peran penting dalam komunikasi interselular, dan banyak di antaranya mengatur fenotip sel punca dalam berbagai konteks termasuk tumor. 
Analisis Ekspresi Protein TLR-9, CD90 dan VEGF pada Mesenchymal Stem Cell di Jaringan...

Pratika Yuhyi Hernanda

Sel di lingkungan mikro tumor dapat menghasilkan faktor seperti ligan VEGF, TGF-â, matriks metalo- proteinase (MMPs), FGF, HGF, EGF, SDF-1, IGF, PDGF, Wnt, Notch ligand, dan Hedgehog, yang merangsang sel punca kanker memperbarui diri, menginduksi angiogenesis, dan merekrut tumorassociated macrophages (TAM), neutrofil, dan sel mast, yang mengeluarkan faktor pertumbuhan tambahan yang mendorong invasi sel tumor dan metastasis. MSC telah terlibat dalam tumorigenesis melalui beberapa mekanisme, termasuk mempromosikan proliferasi dan metastasis sel kanker dan meningkatkan angiogenesis (Liu et al, 2011).

CD-90 (Cluster of Differentiation 90) adalah protein pada permukaan sel yang satu domain dengan V-like imunoglobulin $\mathrm{V}$, dan dapat digunakan sebagai penanda pada berbagai stem cell (Ades et al, 1980). Dari hasil pewarnaan immunofluorescence CD-90 yang dilakukan pada MSC adiposa dibandingkan dengan MSC osteosarkoma, ekspresi CD-90 pada MSC osteosarkoma terlihat lebih tinggi dibandingkan pada MSC adiposa walaupun perbedaannya tidak signifikan. Peningkatan ekspresi CD90 juga ditemukan pada sel stroma pada kanker prostat dimanamesenchymal stem cell merupakan bagian dari sel stroma (Zhao and Peehl, 2000). Sel stromal dengan ekspresi CD-90 yang tinggi juga meningkatkan pertumbuhan dan migrasi tumor serta meningkatkan respon imun adaptif (Huynh et al, 2016).

Adapun Vascular Endothelial Growth Factor (VEGF) adalah protein sinyal yang dihasilkan oleh sel yang menstimulasi pembentukan pembuluh darah yang terlibat dalam vasculogenesis (pembentukan de novo dari sistem sirkulasi embrionik) serta angiogenesis (pertumbuhan pembuluh darah dari pembuluh darah yang sudah ada sebelumnya) (Senger et al, 1983). Ekspresi VEGF pada MSC osteosarkoma terlihat sedikit menonjol dibanding pada MSC adiposa namun perbedaan antara keduanya tidak signifikan dengan $P$ value $=$ 0.066. Sekresi VEGF pada MSC merupakan faktor penting untuk menentukan potensi angiogenesis MSC, dimana pada sel tumor atau kanker peningkatan angiogenesis akan mempercepat pertumbuhan dan migrasi tumor (Beckermann et al, 2008).

TLR9 adalah reseptor penting yang diekspresikan dalam sel-sel imun termasuk sel dendritik, makrofag, sel NK, dan sel-sel penyaji antigen lainnya (Du et al, 2000). TLR9 mengikat DNA yang ada di bakteri dan virus, dan memicu sinyal kaskade yang mengarah ke respon sitokin pro-inflamasi (Martínez-Campos et al, 2017). Ekspresi TLR9 sangat menonjol pada MSC 
ISSN 1978-2071 (Print); ISSN 2580-5967 (Online) Jurnal IImiah Kedokteran Wijaya Kusuma 8(2) : 108-117, September 2019

osteosarkoma dan terdapat perbedaan yang signifikan dengan MSC adiposa dengan dengan $P$ value $=0.00$. Dengan demikian TLR9 dapat menjadi perhatian pada penelitian selanjutnya untuk menelaah mekanisme MSC yang memicu pertumbuhan osteosarkoma.

\section{RINGKASAN}

Dari hasil penelitian ini dapat diketahui bahwa ekspresi CD-90, VEGF dan TLR9 berbeda-beda untuk MSC dari sumber yang berbeda, terutama untuk MSC dari jaringan tumor dapat kita lihat adanya peningkatan yang signifikan pada protein TLR9. Penelitian ini terbatas pada jaringan tumor osteosarkoma, sehingga perlu dilanjutkan pada jaringan tumor lainnya.Dengan demikian CD90, VEGF dan terutama TLR9 dapat menjadi perhatian pada penelitian selanjutnya untuk menelaah mekanisme MSC yang memicu pertumbuhan tumor untuk kepentingan target terapi serta dapat digunakan untuk deteksi protein penting dalam MSC untuk modifikasi terapi MSC pada pasien.

\section{DAFTAR PUSTAKA}

Ades EW, Zwerner RK, Acton RT, and Balch CM, 1980. Isolation and partial characterization of the human homologue of Thy-1. Journal of
Experimental Medicine, 151: 400406.

Beckermann B, Kallifatidis G, Groth A, Frommhold D, Apel A, et al, 2008. VEGF expression by mesenchymal stem cells contributes to angiogenesis in pancreatic carcinoma. British journal of cancer, 99(4): 622-631.

Du X, Poltorak A, Wei Y, and Beutler B, 2000. Three novel mammalian toll-like receptors: gene structure, expression, and evolution. European cytokine network, 11(3): 362-71.

Hernanda PY, Pedroza-Gonzales A, van der Laan LJW, Janssen HLA, Peppelenbosch MP, and Pan Q, 2013a. 1050 Human Liver Carcinomas Recruit Mesenchymal Stem/Stromal Cells That Can Promote Tumor Growth Via Paracrine Signaling. Journal of Hepatology, 58: S431-S431.

Hernanda PY, Pedroza-Gonzalez A, Sprengers D, Peppelenbosch MP, and Pan Q, 2014. Multipotent mesenchymal stromal cells in liver cancer: implications for tumor biology and therapy. Biochim Biophys Acta, 1846(2): 439-45. 
Analisis Ekspresi Protein TLR-9, CD90 dan VEGF pada Mesenchymal Stem Cell di Jaringan...

Pratika Yuhyi Hernanda

Hernanda PY, Pedroza-Gonzalez A, van der

Laan L, Broker ME, Hoogduijn

MJ, et al, 2013b. Tumor

promotion through the

mesenchymal stem cell

compartment in human

hepatocellular carcinoma.

Carcinogenesis, 34: 2330-40.

Horwitz EM, Le Blanc K, Dominici M, Mueller I, Slaper-Cortenbach I, Marini FC, Deans RJ, et $a$ l and International Society for Cellular Therapy, 2005. Clarification of the nomenclature for MSC: The International Society for Cellular Therapy position statement. Cytotherapy, 7(5): 393-5.

Huynh PT, Beswick EJ, Coronado YA, Johnson $\mathrm{P}, \mathrm{O}^{\prime}$ Connell MR, Watts $\mathrm{T}$, et al, 2016. CD 90+ stromal cells are the major source of IL-6, which supports cancer stem-like cells and inflammation in colorectal cancer. International journal of cancer, 138(8): 19711981.

Liu S, Ginestier SC, Ou SJ, Clouthier SG, Patel SH, Monville F, et al, 2011. Breast cancer stem cells are regulated by mesenchymal stem cells through cytokine networks. Cancer research, 71(2): 614-24.
Martinez-Campos C, Burguete-Garcia Al, and Madrid-Marina V, 2017. Role of TLR9 in Oncogenic VirusProduced Cancer. Viral Immunol, 30 (2): 98-105.

Senger DR, Galli SJ, Dvorak AM, Perruzzi CA, Harvey VS, and Dvorak HF, 1983. Tumor cells secrete a vascular permeability factor that promotes accumulation of ascites fluid. Science, 219(4587): 983985.

Sobacchi C, Palagano E, Villa A, and Menale C, 2017. Soluble Factors on Stage to Direct Mesenchymal Stem Cells Fate. Front Bioeng Biotechnol, 5, 32.

Vineis P, Illari P and Russo F, 2017. Causality in cancer research: a journey through models in molecular epidemiology and their philosophical interpretation. Emerg Themes Epidemiol, 14: 7.

Xie T and Li L, 2007. Stem cells and their niche: an inseparable relationship. The Company of Biologists Ltd.

Zhao H and Peehl DM, 2009. Tumor-promoting phenotype of CD90hi prostate cancer-associated fibroblasts. The Prostate, 69(9): $\quad 991-1000$ 